\title{
Direct Synthesis of Sodalite from Kaolin: The Influence of Alkalinity
}

\author{
Meyga Evi Ferama Sari ${ }^{1 *}$, Suprapto $^{2}$, and Didik Prasetyoko² \\ ${ }^{1}$ Department of Chemistry, Malang State University, Jl. Semarang No. 5, Sumbersari, Lowokwaru, Malang 65145, Indonesia \\ ${ }^{2}$ Department of Chemistry, Institut Teknologi Sepuluh Nopember, Jl. Raya ITS, Keputih, Sukolilo, Surabaya, 60111, Indonesia
}

Received May 22, 2017; Accepted January 10, 2018

\begin{abstract}
Alkalinity is one of the most important factors that influences the crystallization process of zeolite and the product properties. The influence of alkalinity on the synthesis of sodalite from kaolin without calcination was reported in this research. The synthesis of sodalite using molar ratio of $\mathrm{Na}_{2} \mathrm{O} / \mathrm{Al}_{2} \mathrm{O}_{3}=x, \mathrm{H}_{2} \mathrm{O} / \mathrm{Na}_{2} \mathrm{O}=128 / x$ and $\mathrm{SiO}_{2} / \mathrm{Al}_{2} \mathrm{O}_{3}=2 / x$, where $x$ was the variation of molar ratio of alkalinity: 10, 20, 30, and 40. The synthesis has done by stirring for $6 \mathrm{~h}$, without aging, and the crystallization time was $24 \mathrm{~h}$ under hydrothermal method $\left(100{ }^{\circ} \mathrm{C}\right)$. The products were characterized by X-ray Diffraction (XRD), Fourier Transform Infrared Spectroscopy (FTIR), and Scanning Electron Microscopy-Energy Dispersive X-ray (SEM-EDX). The XRD pattern and FTIR spctra shown that pure sodalite was formed by using molar ratio of alkalinity 10,20, and 30. The crystallinity and particle size increase along with increasing of alkalinity. Quartz was formed by using molar ratio of alkalinity 40.
\end{abstract}

Keywords: sodalite; direct synthesis; kaolin; alkalinity

\section{ABSTRAK}

Alkalinitas merupakan salah satu faktor yang penting pada pembentukan kristal zeolit dan karakter produk yang dihasilkan. Pengaruh alkalinitas pada sintesis sodalit dari kaolin secara langsung dilaporkan pada penelitian ini. Sintesis dilakukan dengan perbandingan rasio molar $\mathrm{Na}_{2} \mathrm{O} / \mathrm{Al}_{2} \mathrm{O}_{3}=x, \mathrm{H}_{2} \mathrm{O} / \mathrm{Na}_{2} \mathrm{O}=128 / x$ dan $\mathrm{SiO}_{2} / \mathrm{Al}_{2} \mathrm{O}_{3}=2 / x$, dengan x merupakan variasi rasio molar alkalinitas: 10, 20, 30, dan 40. Sintesis dilakukan dengan pengadukan selam 6 jam, tanpa aging, dan dilakukan hidrotermal pada suhu $100{ }^{\circ} \mathrm{C}$ selama 24 jam. Produk yang dihasilkan dikarakterisasi menggunakan X-ray Diffraction (XRD), Fourier Transform Infrared Spectroscopy (FTIR), dan Scanning Electron Microscopy-Energy Dispersive X-ray (SEM-EDX). Hasil karakterisasi XRD dan FTIR menunjukkan bahwa sodalit terbentuk pada rasio molar alkalinitas sebesar 10, 20, dan 30, sedangkan kuarsa terbentuk pada rasio molar alkalinitas sebesar 40. Kristalinitas dan ukuran partikel semakin besar seiring dengan meningkatnya rasio molar alkalinitas.

Kata Kunci: sodalit; sintesis secara langsung; kaolin; alkalinitas

\section{INTRODUCTION}

Zeolite is porous material with a three-dimensional framework structure of crystalline aluminosilicate that forms uniformly sized pores and commonly referred as molecular sieves. The empirical formula for zeolite is $\mathrm{M}_{2 / n} \mathrm{O} . \mathrm{Al}_{2} \mathrm{O}_{3} . y \mathrm{SiO}_{2} . w \mathrm{H}_{2} \mathrm{O}$, where $y$ is $2-200, n$ is the cation valence, and $w$ represents the water contained in the intracrystalline channel of zeolite [1]. The frameworks are composed of $\left[\mathrm{SiO}_{4}\right]^{4-}$ and $\left[\mathrm{AlO}_{4}\right]^{5-}$ tetrahedral, which corner-share to form different open structures. The tetrahedrals are linked together to form cages connected by pore opening of defined size; depending on the structure type, the pores size range from approximately 0.3-1 $\mathrm{nm}$ [2]. Zeolite has high thermal, mechanical and chemical stability, therefore

* Corresponding author. Tel : +62-85646162520

Email address : didik.prasetyoko@gmail.com they have widely been used as catalysts, adsorbents, and ion exchangers [3].

Sodalite is a kind of zeolite that has a sixmembered ring aperture framework structure with a pore size of $2.8 \AA$ [4]. Sodalite is crystalline microporous tectosilicate with the general composition of $\mathrm{Na}_{8}\left[\mathrm{AlSiO}_{4}\right]_{6}(\mathrm{X})_{2}$, where $\mathrm{X}$ is a monovalent guest anion [5]. Because of its small pore size and high ion exchange capacity, sodalite has attracted considerable attentions for their potential applications such as optical material [6], waste management [7], hydrogen storage [8], hydrogen separation [9] and catalyst support [10].

Some natural mineral materials have been used to synthesize sodalite. For instance, nano-sized sodalite crystals have been obtained by solid-solid transformation of $\mathrm{Al}_{2} \mathrm{O}_{3}$ pillared clay in the alkaline solution [11-12]. Interstratified illite-smectite [13], perlite

Meyga Evi Ferama Sari et al. 
[14] and coal fly ash [15-16] have been converted into micro-sized sodalite crystals or spheres through alkaline hydrothermal treatment. Among other sodalite natural mineral material sources, kaolin mineral, which mainly contains kaolinite $\left[\mathrm{Si}_{2} \mathrm{Al}_{2} \mathrm{O}_{5}(\mathrm{OH})_{4}\right]$, seems to be a more promising candidate to synthesize sodalite because it consists of high $\mathrm{Si}, \mathrm{Al}$ as the main sources to synthesize of zeolite, cheap, and easy to find in Indonesia. The mineral can be either formed by the decomposition of heavier minerals, such as feldspar, granite and aluminum silicate or by weathering process of mica and muscovite. Kaolinite structure consists of a tetrahedral silica sheet alternating with an octahedral alumina sheet [17].

The use of kaolinite as the source of alumina and silica in the zeolite synthesis has been reported previously [18]. There are two different methods to activate kaolinite, namely conventional hydrothermal synthesis and alkaline calcinations followed by hydrothermal reaction. Conventional hydrothermal involves three major chemical processes in the reaction between kaolinite and alkaline solution: dissolution of kaolinite, $\mathrm{Si}$ and $\mathrm{Al}$ release, followed by formation of zeolitic material [19]. The dissolution of kaolinite is favored at a high $\mathrm{NaOH}$ concentrations, which revealed by the occurrence of sodalite and cancrinite [19]. Kaolinite is usually converted to a more reactive phase (metakaolinite) by heating above the dehydroxylation temperature between 450 and $600{ }^{\circ} \mathrm{C}$. The most common product obtained was zeolite LTA [19].

The alkalinity of the reaction medium seems to be one of the key factors for a successful synthesis of sodalite. However, there is still a lack of systematic reports on the effects of the alkaline medium to the crystal morphology of sodalite. In this research, sodalite had been synthesized from natural kaolin without calcinations step via hydrothermal synthesis method. The effects of alkalinity of the reaction medium on the final crystalline product have been studied.

\section{EXPERIMENTAL SECTION}

\section{Materials}

Sodalite was prepared using kaolin (kaolinite, $\left.\mathrm{Al}_{4}\left(\mathrm{Si}_{4} \mathrm{O}_{10}\right)(\mathrm{OH})_{8}\right)$ from Bangka Belitung, Indonesia. Based on the XRF analysis, kaolin from Bangka Belitung consists of (wt.\%): $\mathrm{Al}_{2} \mathrm{O}_{3}$ (22\%), $\mathrm{SiO}_{2}(57 \%), \mathrm{P}_{2} \mathrm{O}_{5}$ (3.9\%), $\mathrm{K}_{2} \mathrm{O}(3.22 \%), \mathrm{CaO}(1.8 \%), \mathrm{TiO}_{2}(2.2 \%), \mathrm{V}_{2} \mathrm{O}_{5}$ $(0.15 \%), \mathrm{Fe}_{2} \mathrm{O}_{3}(8.89 \%), \mathrm{CuO}(0.31 \%), \mathrm{Ga}_{2} \mathrm{O}_{3}(0.074 \%)$, $\mathrm{ZrO}_{2}(0.22 \%)$, and $\mathrm{BaO}(0.77 \%) ; \mathrm{NaOH}$ (sodium hydroxide, pellet, Applichem, > 99.5\%); sodium aluminate anhydrous $\left(\mathrm{NaAlO}_{2}\right.$, sigma Aldrich, $\mathrm{Al}_{2} \mathrm{O}_{3} 50$ $56 \%, \mathrm{Na}_{2} \mathrm{O} 40-45 \%$ ) was used as aluminium source; and demineralized water.

\section{Procedure}

\section{Synthesis}

The synthesis was conducted by hydrothermal method without calcination process (direct method). Kaolin (3 g for each bottle) was transferred into different polypropyl bottle containing 4 different concentrations of $\mathrm{NaOH}$ solution. The $\mathrm{NaOH}$ solution was prepared by dissolving $8.64,17.80,26.96$ and $36.11 \mathrm{~g}$ in $26.37 \mathrm{~g}$ demineralized water that correspond to molar ratio of $\mathrm{NaOH}$ solution of $10,20,30$ and 40 , respectively. Then, each mixture was stirred for 15 minutes. Subsequently, $0.90 \mathrm{~g}$ of sodium aluminate was added to the mixture while stirring for another 15 minutes. The mixture was further stirred at room temperature for 24 hours. After 24 hours, it was heated inside a hundred-degree celsius oven for 24 hours to carry out the hydrothermal crystallization. After the hydrothermal treatment, the product was filtrated and washed using demineralized water until the $\mathrm{pH}$ of the filtrate is under 9 . The solid was dried at $100{ }^{\circ} \mathrm{C}$ overnight. S-standard represented the sodalite standard for the sample. S-10, S-20, S-30 and S-40 represented the synthesized products with molar ratio of alkalinity $10,20,30$, and 40 , respectively.

\section{Characterization}

X-ray powder diffraction patterns of crystal phase of the products were recorded on a Philips Expert with $\mathrm{CuK}_{\alpha}(40 \mathrm{kV}, 30 \mathrm{~mA})$ radiation in the range $2 \theta=5-50^{\circ}$. The infrared spectra (range $450-1400 \mathrm{~cm}^{-1}$ ) of characteristic vibration bands were monitored by FTIR Shimadzu Instrument Spectrum One 8400S. SEM investigation and EDX analysis were performed on ZEISS EVO MA 10 scanning electron microscope coupled with a BRUKER 129 EV energy disperse X-ray for $\mathrm{Al}, \mathrm{Si}, \mathrm{Na}$, and $\mathrm{O}$.

\section{RESULT AND DISCUSSION}

\section{XRD Characterization}

XRD analysis is used to identify the crystalline phase, crystal structure and crystallinity of the samples. The diffractograms of the synthesized products are shown as Fig. 1. Based on XRD pattern, it can be seen that the kaolin sample contains kaolinite phase (96900-9231) dominantly at $2 \theta=12.36,19.91,20.37$, $24.89,34.88,35.95,38.46,39.23$ and $45.52^{\circ}$. The main peaks of sodalite at $2 \theta$ angle are $14.00,24.43,31.79$, 34.86 and $43.01^{\circ}$. Based on the diffractograms, sodalite was formed when the ratio of $\mathrm{NaOH}$ was 10 , 20 , and 30 . When the ratio of $\mathrm{NaOH}$ was 40 , quartz was formed dominantly. Table 1 shows the phases and yield of the synthesized products. 


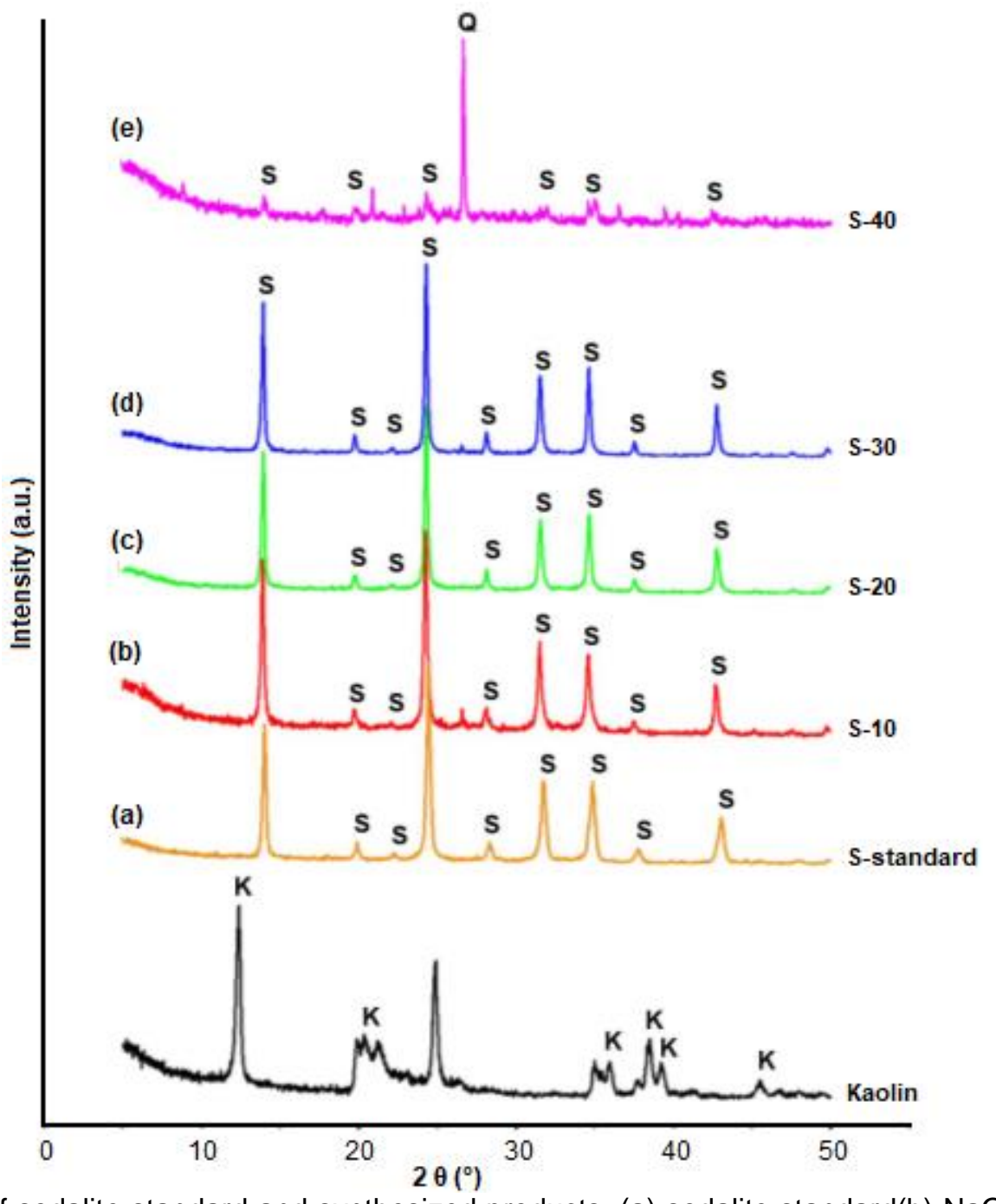

Fig 1. XRD pattern of sodalite standard and synthesized products. (a) sodalite standard(b) $\mathrm{NaOH} 10$, (c) $\mathrm{NaOH} 20$, (d) $\mathrm{NaOH}$ 30, and (e) $\mathrm{NaOH}$ 40. Q: quartz, S: sodalite

Table 1. The phases and yield of the synthesis products

\begin{tabular}{ccccc}
\hline No & Sample & Product & dxRD $(\mathrm{nm})$ & Yield $(\mathrm{g})$ \\
\hline 1 & $\mathrm{NaOH} \mathrm{10}$ & Sodalite & 33.55 & 2.7260 \\
2 & $\mathrm{NaOH} \mathrm{20}$ & Sodalite & 38.55 & 3.2727 \\
3 & $\mathrm{NaOH} \mathrm{30}$ & Sodalite & 42.69 & 2.4148 \\
4 & $\mathrm{NaOH} \mathrm{40}$ & Quartz & - & 0.0439 \\
\hline
\end{tabular}

Quartz was formed dominantly at S-40 sample, but there are some peaks of sodalite (weak peaks). Sodalite was not formed well in this ratio because the $\mathrm{OH}^{-}$level is too high and causes high solubility of $\mathrm{Si}$ and $\mathrm{Al}$. It was proved by the very small yield of the synthesized product, i.e. $0.0439 \mathrm{~g}$ (Table 1). It is shown that sodalite has low crystallinity in high alkaline condition. The optimum yield can be reached by using $\mathrm{NaOH} 20$ $(3.2727 \mathrm{~g})$ where $\mathrm{Si}$ and $\mathrm{Al}$ in kaolin can dissolve optimally, therefore the optimum yield can be reached.
The particles size of the sodalite samples ( $d \times R D$ ) were calculated by the Scherer's Eq. 1 using the line broadening of the 211 diffraction peak [20]. The 211 peak was chosen because it has the highest relative intensity compared to the other characteristic peaks of sodalite. It can be considered as the representative of the particle size of the sample. B value of each sodalite was calculated from the 211 peak diffraction using Gaussian Fit in Origin software.

$\mathrm{d}_{\mathrm{XRD}}=\frac{0.9 \lambda}{\mathrm{B} \cos \theta}$

In Eq.1, $\lambda$ is wave length of X-ray used $(0.154060 \mathrm{~nm}), B$ is full width at half maximum 211 diffraction peak after substation of line broadening due to the apparatus, $\theta$ is Bragg angle.

Table 2 shows the particle size ( $d x R D)$ of the synthesized sodalite. Based on XRD analysis, the 
particle size of sodalite samples were 47.38, 33.55, 38.55 and $42.69 \mathrm{~nm}$ for the sodalite standard, S-10, S20 and S-30, respectively.

Based on the dxRD calculations, higher alkaline condition will form larger particle size. Theoretically, at higher alkaline condition, smaller particle size should be found. However, the results of particle size calculation from the present study did not match with the theory. This is because at the higher alkalinity, the system obviously contains more $\mathrm{OH}^{-}$concentration. If the concentration of $\mathrm{OH}^{-}$is high, more $\mathrm{Si}$ and $\mathrm{Al}$ can be dissolved. If more $\mathrm{Si}$ and $\mathrm{Al}$ dissolved, there was higher possibility that the crystallization process occurs earlier than expected, thus the crystal growth can last longer. The longer time for crystals growth, the larger crystals were formed. The results are similar with previous report [20].

\section{FTIR Characterization}

FTIR spectra (Fig. 2(a-e)) show that the characteristic band of sodalite at approximately 991$997 \mathrm{~cm}^{-1}$ wavenumber, which was assigned to the T-O$\mathrm{T}$ asymmetric stretching $(\mathrm{T}=\mathrm{Si}, \mathrm{Al})$, at 715 and $657 \mathrm{~cm}^{-1}$ due to the T-O-T symmetric stretch [16], at 459 and below $430 \mathrm{~cm}^{-1}$ due to bending vibration of O-T-O and

Table 2. Table of $d x R D$ of synthesized sodalite at 211 peak

\begin{tabular}{cccccc}
\hline No & Sample & B & $\theta$ & $\cos \theta$ & dxRD $(\mathrm{nm})$ \\
\hline 1 & S-standard & 0.00292590 & 12.228 & 0.9998 & 47.38 \\
2 & S-10 & 0.00422679 & 12.122 & 0.9777 & 33.55 \\
3 & S-20 & 0.00367941 & 12.142 & 0.9776 & 38.55 \\
4 & S-30 & 0.00332252 & 12.139 & 0.9776 & 42.69 \\
\hline
\end{tabular}

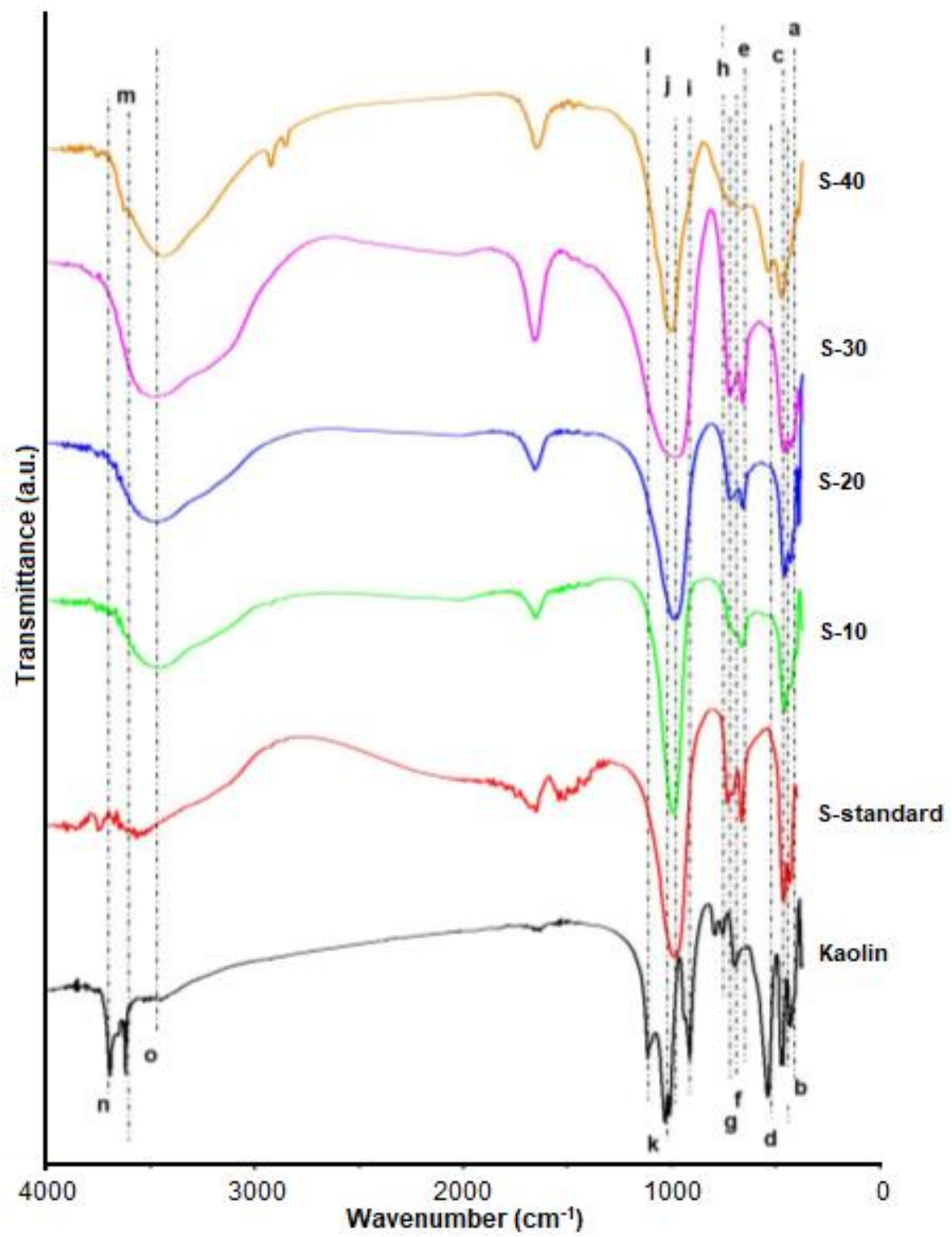

Fig 2. FTIR spectra of kaolin, S-10, S-20, S-30, and S-40 
Table 3. The wavenumber $\left(\mathrm{cm}^{-1}\right)$ of FTIR spectra of kaolin, S-standard, S-10, S-20, S-30, and S-40

\begin{tabular}{|c|c|c|c|c|c|c|c|}
\hline \multirow{3}{*}{ Code } & \multicolumn{6}{|c|}{ Wavenumber $\left(\mathrm{cm}^{-1}\right)$} & \multirow{3}{*}{ Type of vibration } \\
\hline & \multicolumn{6}{|c|}{ Sample } & \\
\hline & Kaolin & S-standard & S-10 & S-20 & S-30 & S-40 & \\
\hline a & 430 & 432 & 428 & 430 & 428 & - & $\begin{array}{l}<430 \mathrm{~cm}^{-1} \text { [the change of } \mathrm{Si}-\mathrm{O} \text { shape], }>430 \mathrm{~cm}^{-1} \\
\text { [bending vibration of } \mathrm{O}-\mathrm{T}-\mathrm{O}(\mathrm{T}=\mathrm{Si} \text { or } \mathrm{Al}) \text { and } 4 \text { single } \\
\text { ring of sodalite }(\mathrm{S} 4 \mathrm{R})]\end{array}$ \\
\hline$b$ & 469 & 462 & - & - & - & 472 & The change of Si-O shape \\
\hline c & - & - & 459 & 457 & 457 & - & Bending vibration of $\mathrm{O}-\mathrm{T}-\mathrm{O}(\mathrm{T}=\mathrm{Si}$ or $\mathrm{Al})$ \\
\hline$d$ & 538 & - & - & - & - & 534 & The change of $\mathrm{Al}-\mathrm{O}$ shape \\
\hline e & - & 661 & 660 & 658 & 658 & 661 & Symmetry stretching vibration of T-O-T $(\mathrm{T}=\mathrm{Si}$ of $\mathrm{Al})$ \\
\hline$f$ & 696 & - & - & - & - & - & The change of $\mathrm{AlO}-\mathrm{H}$ shape \\
\hline$g$ & - & 729 & 717 & 719 & 719 & - & Symmetry stretching vibration of $\mathrm{T}-\mathrm{O}-\mathrm{T}(\mathrm{T}=\mathrm{Si}$ or $\mathrm{Al})$ \\
\hline $\mathrm{h}$ & 754 & - & - & - & - & - & Symmetry stretching vibration of $\mathrm{Si}-\mathrm{O}-\mathrm{Si}$ \\
\hline $\mathrm{i}$ & 912 & - & - & -- & - & 914 & $\delta(\mathrm{Si}-\mathrm{OH})$ \\
\hline j & - & 981 & 991 & 984 & 974 & 997 & Asymmetry stretching vibration of $\mathrm{T}-\mathrm{O}-\mathrm{T}(\mathrm{T}=\mathrm{Si}$ or $\mathrm{Al})$ \\
\hline $\mathrm{k}$ & 1032 & - & - & - & - & - & Asymmetry stretching vibration of $\mathrm{T}-\mathrm{O}(\mathrm{T}=\mathrm{Si}$ or $\mathrm{Al})$ \\
\hline I & 1114 & - & - & - & - & - & Si-O stretching vibration \\
\hline $\mathrm{m}$ & 3620 & - & - & - & - & - & Inner-hydroxyl $(\mathrm{O}-\mathrm{H})$ vibration \\
\hline $\mathrm{n}$ & 3694 & - & - & - & - & - & Inner-surface hydroxyl $(\mathrm{O}-\mathrm{H})$ vibration \\
\hline 0 & $\begin{array}{c}3400 \\
\text { (broad) }\end{array}$ & - & 3458 & 3468 & 3470 & 3427 & $\mathrm{O}-\mathrm{H}$ vibration of water \\
\hline
\end{tabular}

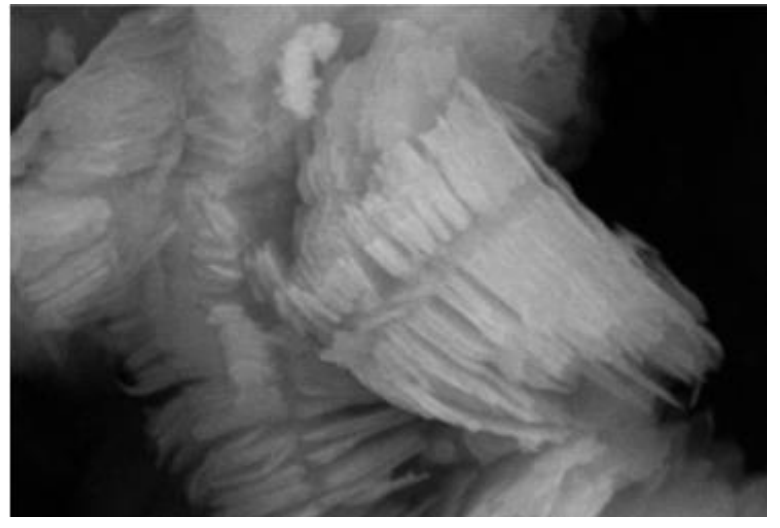

Fig 3. SEM image of kaolin
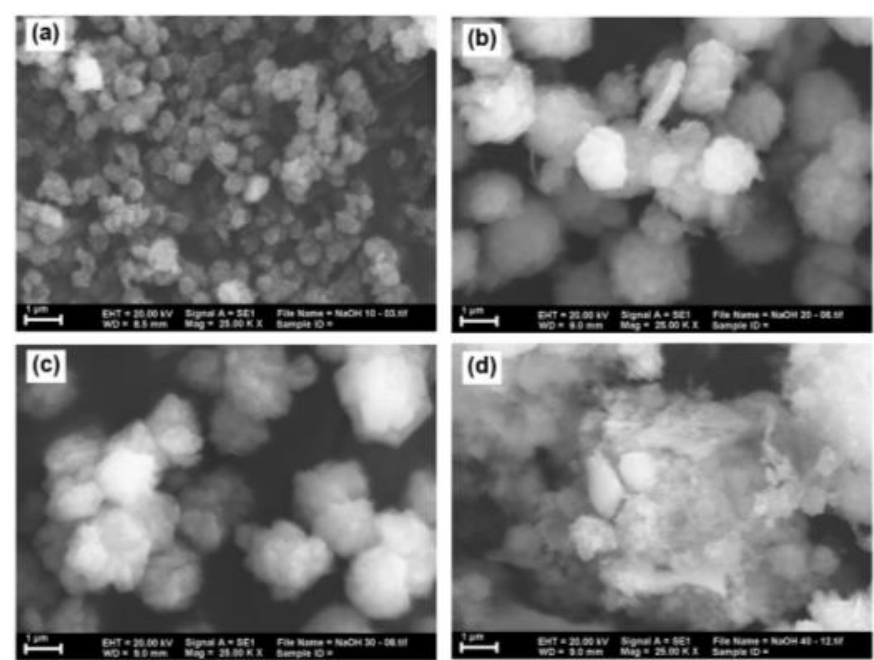

Fig 4. SEM image of synthesized products. (a) S-10, (b) S-20, (c) S-30, and (d) S-40 the bending vibration of single four-membered ring (S4R) of sodalite, respectively [21]. No adsorption below $430 \mathrm{~cm}^{-1}$ for $\mathrm{S}-40$ sample indicated that the sodalite was transformed into quartz. Table 3 shows the wavenumber of FTIR spectra of kaolin and the sodalite samples.

\section{SEM-EDX Characterization}

The morphology of kaolin from Bangka Belitung is shown at Fig. 3. Based on the SEM image, the morphology of kaolin consists of layers (sheets). The same morphology of kaolin (sheets) was also reported [22].

Fig. 4(a-d) shows the SEM images of the synthesized products with different ratio of $\mathrm{NaOH}$. Based on Fig. 4(a-c), the morphology of S-10, S-20 and S-30 were aggregates which have the particle size of 500-700, 1000-1300 and 1500-1800 nm respectively. The SEM characterization of the synthesized sodalite sample shows that the particle size is proportional to the degree of the alkalinity, i.e. particle size is bigger at higher alkalinity. Similar results was obtained at low alkalinity ratio $\left(\mathrm{xNa}_{2} \mathrm{O} / 5 \mathrm{SiO}_{2}, \mathrm{x}=\right.$ 10, 15 and 19) and micro sized sodalites were produced at high alkalinity ratio $\left(x \mathrm{xa}_{2} \mathrm{O} / 5 \mathrm{SiO}_{2}, \mathrm{x}=24\right.$ and 29) [20]. Fig. 4(d) shows the morphology of the S40 sample. Based on Fig. 4(d), the morphology of S-40 was irregular (cotton-shaped aggregates).

The EDX results of S-10, S-20, S-30 and S-40 samples are shown in Table 4. Based on EDX results in Table 4, the ratio of Si/Al samples S-10, S-20, S-30 
Table 4. EDX result of synthesized samples

\begin{tabular}{ccccccc}
\hline \multirow{2}{*}{ No } & \multirow{2}{*}{ Sample } & Product & \multicolumn{3}{c}{$\mathrm{Wt}(\%)$} & \multirow{2}{*}{ Si/Al ratio } \\
\cline { 4 - 6 } & & & $\mathrm{Si}$ & $\mathrm{Al}$ & $\mathrm{Na}$ & \\
\hline 1 & $\mathrm{~S}-10$ & Sodalite & 4.74 & 6.45 & 7.81 & 0.709 \\
2 & $\mathrm{~S}-20$ & Sodalite & 10.62 & 13.76 & 12.31 & 0.744 \\
3 & $\mathrm{~S}-30$ & Sodalite & 10.61 & 13.90 & 13.29 & 0.736 \\
4 & $\mathrm{~S}-40$ & Quartz (dominant) & 6.87 & 7.06 & 2.60 & 0.938 \\
\hline
\end{tabular}

and S-40 were 0.709, 0.744, 0.736 and 0.938, respectively. Generally, the $\mathrm{Si} / \mathrm{Al}$ ratio of synthesized products increased along with increased ratio of alkalinity. It indicates that at higher alkalinity, solubility of $\mathrm{Si}$ and $\mathrm{Al}$ is higher. While the ratio of Si/Al for S-10, S-20 and S-30 samples were not significantly different each other, the ratio of $\mathrm{Si} / \mathrm{Al}$ was highest in the $\mathrm{S}-40$ sample compared to the rest of the samples. Lower Si/Al ratio indicated that there was more aluminum usage.

\section{CONCLUSION}

Alkalinity of the reaction medium is one of the important factors for synthesis of sodalite by hydrothermal method. Synthesis use molar ratio of alkalinity 10, 20 and 30 produced sodalite, while 40 produced quartz. The increases ratio of alkalinity, the increases particle size. The highest yield can be reached by using molar ratio of alkalinity 20 .

\section{ACKNOWLEDGEMENT}

This work was supported by the Ministry of Research and Higher Education, Indonesia, under "PUPT" research grant No. 003246.18/IT2.11/PN.08/ 2015.

\section{REFERENCES}

[1] Flanigen, E.M., Broach, R.W., and Wilson, S.T., 2010, "Introduction" in Zeolites in Industrial Separation and Catalysis, Kulprathipanja, S. (Eds.), Wiley-VCH Verlag GmbH \& Co. KGaA, Weinheim, $1-26$.

[2] Szostak, R., 1989, Molecular Sieves: Principles of Synthesis and Identification, Springer Science \& Business Media, New York.

[3] Mirfendereski, M., and Mohammadi, T., 2011, Investigation of hydrothermal synthesis parameters on characteristics of $\mathrm{T}$ type zeolite crystal structure, Powder Technol., 206 (3), 345-352.

[4] Jiang, J., Gu, X., Feng, L., Duanmu, C., Jin, Y., Hu, T., and $\mathrm{Wu}, \mathrm{J} ., 2012$, Controllable synthesis of sodalite submicron crystals and microspheres from palygorskite clay using a two-step approach, Powder Technol., 217, 298-303.

[5] Ocanto, F., Álvarez, R., Urbina, C., Lieb, A., and
Linares, C., 2008, Influence of the alkalinity and $\mathrm{NO}_{3}{ }^{-} / \mathrm{Cl}^{-}$anionic composition on the synthesis of the cancrinite-sodalite system, Microporous Mesoporous Mater., 116 (1-3), 318-322.

[6] Arieli, D., Vaughan, D.E.W., and Goldfarb, D., 2004, New synthesis and insight into the structure of blue ultramarine pigments, J. Am. Chem. Soc., 126 (18), 5776-5788.

[7] Buhl, J.C., Gesing, T.M., Kerkamm, I., and Gurris, C., 2003, Synthesis and crystal structure of cyanate sodalite $\left|\mathrm{Na}(\mathrm{OCN})_{2}\right|\left[\mathrm{Al}_{6} \mathrm{Si}_{6} \mathrm{O}_{24}\right]$, Microporous Mesoporous Mater., 65 (2-3), 145153.

[8] Buhl, J.C., Gesing, T.M., and Rüscher, C.H., 2005, Synthesis, crystal structure and thermal stability of tetrahydroborate sodalite $\mathrm{Na}_{8}\left[\mathrm{AlSiO}_{4}\right]_{6}\left(\mathrm{BH}_{4}\right)_{2}$, Microporous Mesoporous Mater., 80 (1-3), 57-63.

[9] Julbe, A., Motuzas, J., Cazevielle, F., Volle, G., and Guizard, C., 2003, Synthesis of sodalite/ $\alpha_{A} \mathrm{Al}_{2} \mathrm{O}_{3}$ composite membranes by microwave heating, Sep. Purif. Technol., 32 (1-3), 139-149.

[10] Ogura, M., Morozumi, K., Elangovan, S.P., Tanada, H., Ando, H., and Okubo, T., 2008, Potassium-doped sodalite: A tectoaluminosilicate for the catalytic material towards continuous combustion of carbonaceous matters, Appl. Catal., B, 77 (3-4), 294-299.

[11] Choy, J.H., Lee, S.R., Han, Y.S., Park, M., and Park, G.S., 2003, Solid-solid transformation mechanism for nanocrystalline sodalite from pillared clay, Chem. Commun., 0 (15), 1922-1923.

[12] Lee, S.R., Park, M., Han, Y.S., and Choy, J.H., 2004, Solid-solid transformation route to nanocrystalline sodalite from Al-PILC at room temperature, J. Phys. Chem. Solids, 65 (2-3), 421-424.

[13] Baccouche, A., Srasra, E., and El Maaoui, M., 1998, Preparation of Na-P1 and sodalite octahydrate zeolites from interstratified illitesmectite, Appl. Clay Sci., 13 (4), 255-273.

[14] Rujiwatra, A., 2004, A selective preparation of phillipsite and sodalite from perlite, Mater. Lett., 58 (14), 2012-2015.

[15] Ngamcharussrivichai, C., Chatratananon, C., Nuntang, S., and Prasassarakich, P., 2008, Adsorptive removal of thiophene and 
benzothiophene over zeolites from Mae Moh coal fly ash, Fuel, 87 (10-11), 2347-2351.

[16] Inada, M., Eguchi, Y., Enomoto, N., and Hojo, J., 2005, Synthesis of zeolite from coal fly ashes with different silica-alumina composition, Fuel, 84 (2-3), 299-304.

[17] Brigatti, M.F., Galan, E., and Theng, B.K.G., 2006, "Structures and Mineralogy of Clay Minerals" in Handbook of Clay Science (Developments in Clay Science), Bergaya, F., Theng, B.K.G., and Lagaly, G. (Eds.), Elsevier, 19-86.

[18] Barrer, H.M., 1982, Hydrothermal Chemistry of Zeolites, Academic Press, London.

[19] Ríos, C.A., Williams, C.D., and Fullen, M.A., 2009, Nucleation and growth history of zeolite LTA synthesized from kaolinite by two different methods,
Appl. Clay Sci., 42 (3-4), 446-454.

[20] Fan, W., Morozumi, K., Kimura, R., Yokoi, T., and Okubo, T., 2008, Synthesis of nanometer-sized sodalite without adding organic additives, Langmuir, 24 (13), 6952-6958.

[21] Yao, J., Wang, H., Ratinac, K.R., and Ringer, S.P., 2006, Formation of colloidal hydroxy-sodalite nanocrystals by the direct transformation of silicalite nanocrystals, Chem. Mater., 18 (6), 13941396.

[22] Lapides, I., and Heller-Kallai, L., 2007, Reactions of metakaolinite with $\mathrm{NaOH}$ and colloidal silicacomparison of different samples (part 2), Appl. Clay Sci., 35 (1-2), 94-98. 